\title{
The Quiet Rise of Medium-Scale Farms in Malawi
}

\author{
Ward Anseeuw ${ }^{1, *}$, Thomas Jayne ${ }^{2}$, Richard Kachule ${ }^{3}$ and John Kotsopoulos ${ }^{4}$ \\ 1 CIRAD \& University of Pretoria-The Center for the Study of Governance Innovation and the Post-Graduate \\ School of Agriculture and Rural Development, University of Pretoria, Pretoria 0002, South Africa \\ 2 Department of Agricultural, Food and Resource Economics, Michigan State University, Justin S. Morrill Hall \\ of Agriculture, 446 West Circle Drive, Room 317c, East Lansing, MI 48824, USA; jayne@anr.msu.edu \\ 3 Centre for Agricultural Research and Development (CARD), Lilongwe University of Agriculture and \\ Natural Resources (LUANAR), P.O. Box 219, Lilongwe, Malawi; richardkachule@gmail.com \\ 4 GovInn-The Center for the Study of Governance Innovation, University of Pretoria, Pretoria 0002, \\ South Africa; john.kotsopoulos@up.ac.za \\ * Correspondence: ward.anseeuw@up.ac.za; Tel.: +27-12-420-50-22; Fax: +27-12-420-36-01
}

Academic Editors: Claudia A. Radel and Jacqueline M. Vadjunec

Received: 1 August 2015; Accepted: 8 June 2016; Published: 24 June 2016

\begin{abstract}
Medium-scale farms have become a major force in Malawi's agricultural sector. Malawi's most recent official agricultural survey indicates that these account for over a quarter of all land under cultivation in Malawi. This study explores the causes and multifaceted consequences of the rising importance of medium-scale farms in Malawi. We identify the characteristics and pathways of entry into farming based on surveys of 300 medium-scale farmers undertaken in 2014 in the districts of Mchinji, Kasungu and Lilongwe. The area of land acquired by medium-scale farmers in these three districts is found to have almost doubled between 2000 and 2015. Just over half of the medium-scale farmers represent cases of successful expansion out of small-scale farming status; the other significant proportion of medium-scale farmers are found to be urban-based professionals, entrepreneurs and/or civil servants who acquired land, some very recently, and started farming in mid-life. We also find that a significant portion of the land acquired by medium-scale farmers was utilized by others prior to acquisition, that most of the acquired land was under customary tenure, and that the current owners were often successful in transferring the ownership structure of the acquired land to a long-term leaseholding with a title deed. The study finds that, instead of just strong endogenous growth of small-scale famers as a route for the emergence of medium-scale farms, significant farm consolidation is occurring through land acquisitions, often by urban-based people. The effects of farmland acquisitions by domestic investors on the country's primary development goals, such as food security, poverty reduction and employment, are not yet clear, though some trends appear to be emerging. We consider future research questions that may more fully shed light on the implications of policies that would continue to promote land acquisitions by medium-scale farms.
\end{abstract}

Keywords: Malawi; medium-scale farmers; land; livelihoods; farmer trajectories; farm expansion; land acquisition; land consolidation; domestic investors

\section{Introduction}

After 40 years of relative inertia, African agriculture seems to have engaged a renewed structural transformation path. According to the most recent literature, the latter mainly concerns transformation in the large-scale farming and agribusiness sectors. Indeed, most of the attention on changing farmland ownership in sub-Saharan Africa over the past few years has been focused on large-scale foreign land investments [1,2], due in part to a rise in global food prices since the mid-2000s. These investments are significant, if not huge, in size, transforming the high-end of the sector and, as Anseeuw and Ducastel [3] note, initiating trends of corporatization and increased international financing 
of the agricultural sectors. Another stream of the literature focuses more on the transformation of the value-chains, in particular the dismantling of international commodity agreements and the liberalization of agricultural and agri-food markets, which are contributing to the restructuring and modernization of markets. Food markets are consequently becoming increasingly consumer-driven and vertically integrated, which leads to the tighter alignment of supply chains and promotes the emergence of fewer large farms [4,5].

Much less developed or analyzed in the literature are, however, the changes affecting other categories of the agricultural sector, such as the small- and medium-scale farmers. Recent national statistics - particularly in Africa-show nonetheless the rapid rise of medium-scale farmers in Africa [6,7]. Nationally representative smallholder surveys do not, however, shed much light on how rapidly medium- and large-scale farms are growing over time, how these farmers have acquired their farms, the prior status of the land they acquired, or the extent to which they are productively utilizing their farms. Nor do they inform whether these dynamics are related to the present renewed interest in agriculture and transformation of the value-chains (as described above), or whether they are more externally driven, or are endogenous processes of smallholder growth.

This paper endeavors to address this vacuum. The motivation is, therefore, to obtain a more detailed understanding of medium-scale farmers-how many there are, the size of their farms, their trajectories including background and socio-demographic characteristics, how they are acquiring their farms, as well as how rapidly they are changing the agricultural landscape and sector's structure overall. To do so, the paper presents the results of an in-depth empirical study implemented in Malawi. It is based on extensive qualitative and quantitative interviews and analyses of 300 farmers, the large majority of whom are classified as medium-scale farmers. Medium-scale farmers are defined here as farmers with holdings between 5 and 50 hectares (ha), occupying an intermediate position between small-scale, semi-subsistence production and larger-scale, more commercial farming.

The following section develops a conceptual framework to analyze medium-scale farmers as well as describes the data and methods underpinning the findings of the study. Section 3 reviews the case of Malawi, giving historical factors influencing the rise of medium-scale farms in Malawi, with particular reference to the country's land institutions. Sections 4 and 5 present the study's findings concerning the characteristics of medium-scale farm households and changes in farmland ownership patterns in Malawi. Section 6 discusses these results using the lens of our conceptual framework and presents agricultural trends and debates, before Section 7 highlights the main conclusions and policy implications of the paper as well as questions for future research.

\section{A Framework for Analyzing Medium-Scale Farmers}

\subsection{Definitions}

Medium-scale landholders/farmers are in this study defined as farmers with a total landholding of between 5 and 50 ha. These medium-scale entities are often characterized as occupying an intermediate position between small-scale, semi-subsistence production and larger-scale, more commercial farming. In accordance with this definition, small-scale farmers are farmers with a total landholding of less than 5 ha; large-scale farmers, with more than 50 ha. This definition often diverges from how government statistical organizations define farm-scale categories, which is typically on the basis of area under cultivation. Moreover, some African governments define medium-scale farms as those between 5 and 20 hectares. Our rationale for defining medium-scale holdings in the way we do is explained below in the methods section.

Three points related to this definition are relevant. First, although "medium-scale" and "emerging" are often used interchangeably, the "emerging farmer" term originally referred to previously disadvantaged farmers, particularly as a result of colonial government policies, who were attempting to make the transition to commercially based agriculture [8]. We deliberately retain the term "medium-scale farmers," both to avoid the debate over this emergent farmer narrative, and also to not 
automatically relate medium-scale to emerging. As made clear below, many medium-scale farms in Malawi may be neither emerging nor disadvantaged with respect to policy. Secondly, "medium-scale farmers" is also the term used by the Malawian authorities; although the size span retained for this category is generally 5 to 10 ha. The larger size retained for this study allowed for the inclusion of estate farms in the sample, to better account for potential new land and agrarian dynamics, and to use this work in comparison with other recent literature from the region [6,7]. Thirdly, the size used for this categorization is the total landholding of the farmer, whether under customary or public land occupation, lease or freehold. This allows us to directly examine the degree of land utilization by farms of different landholding size categories.

\subsection{Literature Review}

The international literature on medium-scale farmers remains rather limited. This is related to the ever prominent debate which situates smallholder vs. large-scale farming [9], neglecting the existence of a large diversity of farming and production systems in-between. The paucity of literature regarding medium-scale farmers is certainly also related to semantics and definitions, as "smallholder" and "small-scale farmer" are often used as catchall terms grouping all farmers that are not large-scale [10].

This being said, the aforementioned questions regarding Malawi's medium-scale farmers are situated at the crossroads of four interrelated bodies of literature, highlighting distinct conceptual frameworks. Each of them focuses on specific features related to the characterization of medium-scale farmers or of their trajectories.

The first body of literature examines concepts of technical efficiency and accumulation driving changes in farm structure over time [11]. On one hand, economic development is considered to be related to the technical improvement of the production processes and to increased labor productivity. Mellor [12] and many others showed that broad-based gains in productivity of small-scale farmers favored better development outcomes in terms of farm growth as well as poverty reduction, employment generation, and overall economic growth. As such, the improvement of farm efficiency and labor productivity is closely linked to capital accumulation trajectories of the production units. Indeed, according to these authors, the improvement of production techniques and of labor productivity allows for the generation of an increasing surplus of marketable production, enabling savings. These savings can then (partly) be reinvested in the means of production (e.g., farm equipment, modern inputs, and land), which further enhances labor productivity. More efficient farmers with favorable access to capital can engage in a virtuous growth and development cycle, established on technical improvement and capital accumulation [13], acquiring farms of less efficient neighbors after they migrate into non-farm jobs, leading to farm consolidation. Even though economists, in particular those who deal with agricultural development [14], have since enriched these founding theories, the supremacy of capital and technical efficiency as the main drivers of change in farmland ownership were rarely questioned. This accumulation pattern leads to agricultural mechanization, greater use of modern inputs, such as hybrid seed and fertilizer, and to increasing size of production units.

The second body of literature regards farm trajectories assessed through farm strategies, and more particularly diversification strategies (see [15-18], among others). Besides diversification undertaken to manage risk, cope with shock, or escape from agriculture in stagnation or in secular decline periods, farmers diversify for accumulation objectives. Reardon et al. [19] note that while diversification (especially driven by pull factors) is usually associated with an upward spiral of incomes and assets for the households, the diversification (by push factors) sometimes extracts households from poverty as well, though perhaps over a longer time period. Anseeuw and Laurent [20] show that, in many developing countries, a large number of farmers are constrained, at least in the early stages of their farming activity, to look for other sources of income in order to cover the costs of building up farm assets. Most of them engage in several independent activities or combine salaried and independent (including farming and non-farming) activities, in order to finance farm assets. 
The third body of literature around medium-scale farmers is related to land dynamics and land acquisitions. The latter is particularly the case in the framework of the present growing interest in farmland [2]. This burgeoning interest in land has mainly led to an expanding literature focusing on foreign direct investment in land, foreign large-scale land acquisitions, etc. [1]. Lately, complementary works have shifted the focus onto what is called "indirect appropriation" [21] and the role of national institutions and domestic elites in the rush for land. The question of domestic elites, who are often urban based, directly relates to the issue of medium-scale farmers and to diversified accumulation patterns, through nonagricultural accumulation [7]. Related to this is, of course, the recurring debate in the development literature about the relative emphasis to place on the roles of endogenous growth of small-scale farmers vs. a more externally driven type of growth through non-farm accumulation, as depicted in the extreme case by the debate of small-scale vs. large-scale farms in fostering agricultural growth and economic development. Reviews [11] have re-affirmed the relevance of smallholder agriculture and its broader political economy effects. Together with the success of Asia's Green Revolution, when hundreds of millions of small-scale farmers rapidly adopted new technologies, this placed small-scale farm productivity at the center of the development agenda. At the same time, disillusionment with limited success of smallholder-based efforts to improve productivity in sub-Saharan Africa [22] and the apparent success of other countries, such as Brazil, in establishing a vibrant agricultural sector based on large farms have led many observers to view the development of large-scale mechanized farming as the appropriate path to modernization of the sector in Africa as well.

Lastly, the medium-scale farmer debate can be linked to the literature on the structural transformation in agriculture, which focuses on farm household activity and income structures in an evolving agricultural context marked by liberalization and trends of increasing economic integration $[23,24]$. This literature reviews the very different levels (and trajectories) of rural diversification among countries at various stages in the structural transformation process. According to this literature's framework, late developers, such as most countries of sub-Saharan Africa, are characterized by an incipient economic transition that is accompanied by an unfinished demographic transition (decrease of mortality rates with lingering high birth rates). This demographic structure leads to growing cohorts of new labor market entrants, which can result in opportunities for growth if the entrants can be accommodated, though if not, it represents a serious political and economic liability [25]. At farm level, Losch et al. [24] emphasize that large-scale integration of agricultural producers into the global economy has not happened. Most producers remain engaged in traditional crops-mainly staples-and in traditional marketing systems characterized by limited contractualization. They show that whereas poorer households diversify to mitigate risks, only households that are relatively well off can make larger investments and begin to specialize to take advantage of these new assets. In sub-Saharan Africa in particular, high levels of risk and limited economic opportunities constrain households' options and hence their economic returns. This situation can generate possible poverty traps for low-income farmers. If we believe that this story applies to much of Africa, then we might posit that the current farm structure in many countries on the continent will not generate broad-based income growth and hence we cannot rely on agriculture to generate the multipliers that lead to structural transformation [7]. There is a good amount of evidence suggesting this hypothesis stemming from the structural transformation literature could indeed be true, seeing how poverty rates have remained relatively high over the past several decades [26]. Considering these socio-economic challenges in light of the dramatic demographic shift underway on the continent, policy orientations should reintegrate these structural issues, stressing the importance of broad-based, inclusive agricultural growth. The latter generates demand for non-farm goods and services, which in turn can pull marginal farmers into better jobs in the non-farm economy, leading-once again-to structural transformation and demographic shifts. 


\subsection{Analytical Framework}

In order to analyze the medium-scale farmers in Malawi, our analytical framework focuses on accumulation patterns and farm trajectories, examining how changes in farmland ownership patterns are associated with the socio-economic characteristics of households in different farm size categories. This leads to an in-depth analysis of farm and household livelihood strategies (where do the medium-scale farmers come from, are they full or part-time farmers, what are their sources of revenue, etc.). On the other hand, we assess the accumulation of farm and land assets by these farmers (how much land they own and/or cultivate, which land they acquired, how and when the land was acquired, etc.). Correlating these two (livelihood and land) will lead to a better understanding of how farm accumulation is happening in Malawi.

The contextualization of such analyses will then contribute to the broader literature discussed above, as related to large-scale land acquisitions and structural transformation in agriculture. Indeed, the livelihood approach will provide insight that contributes to the discussion on whether the farmers' trajectories are endogenous - growing internally out of smallholder agriculture —or, on the contrary, whether farm growth is externally driven through non-farm accumulation. These processes can then be related to the structural transformation processes in which these countries are engaged.

\subsection{Data}

Our analysis is based on a survey of 300 landholders, the large majority of which are "medium-scale" farmers. The survey is based on the implementation of a structured questionnaire, with closed and semi-open questions, leading to a largely descriptive methodological approach. Three hundred farm households were interviewed in the framework of this study. The sampling was done randomly through a sequential (every 5 th or 10th farmer-depending on district) selection on an alphabetical list of the population of target farmers. Although the study focused on medium-scale farmers (5.01-50 ha), the results of the survey also show that 27 small-scale (0.01-5.00 ha) and 14 large-scale farmers have been included (Table 1). The latter mainly resulted from imprecise databases on which the farmers' selection and sampling were realized (see hereafter in Section 2.5 regarding the scope and limitations of the study). These small- and large-scale farmers have been retained, however, and used for comparative purposes allowing for a better understanding of specific characterizing elements related to these different farmer size groups. All farmers were selected from three districts-all situated in Central Malawi: Mchinji, Kasungu and Lilongwe. These districts were selected based on their progressive distances from the largest urban area in the region, the capital Lilongwe, allowing for the assessment of the urban impact on land-use dynamics. The district of Mchinji, straddling the eastern border of Zambia, represents the furthest point from the capital with the eponymous Lilongwe district being the closest. An equal sample per district was retained, with weightings made afterwards according to the proportion of medium-scale farmers per district. The full sample of medium-scale farmers retained is therefore 259, of which 90 were in Mchinji, 87 in Kasungu and 82 in Lilongwe districts (Table 1).

The choice of these districts, and Malawi as a case-study in particular, is all the more relevant as the country has had a long history of estate farmers (lease and freehold farms, established since the Banda era onwards-see Section 3). A large proportion of the total landholdings and area under cultivation is in the hands of one percent of the nation's farmers (who control five or more hectares of land-see Table $2[27,28]$ ), and the vast majority of farmland in this category is controlled by people holding over 10 ha of land. It is also of interest as the country and these districts are characterized by huge land pressures, with a growing rural population and small and decreasing farm sizes over time. 
Table 1. Farming households interviewed in the framework of this research.

\begin{tabular}{ccccc}
\hline Landholding Size (ha) & Total $(\boldsymbol{N}=\mathbf{3 0 0})$ & Mchinji $(\boldsymbol{N}=\mathbf{1 0 4})$ & Kasungu $(\boldsymbol{N}=\mathbf{9 9})$ & Lilongwe $(\boldsymbol{N}=\mathbf{9 7})$ \\
\hline $0-5$ & 27 & 6 & 7 & 14 \\
$5.001-10$ & 168 & 46 & 57 & 65 \\
$10.001-20$ & 73 & 32 & 24 & 15 \\
$20.001-30$ & 9 & 4 & 4 & 1 \\
$30.001-40$ & 6 & 5 & 1 & 0 \\
$40.001-50$ & 3 & 1 & 1 & 1 \\
+50 & 14 & 8 & 5 & 1 \\
\hline
\end{tabular}

Source: Authors' medium-scale farm survey in Mchinji, Kasungu and Lilongwe Districts undertaken by Lilongwe University of Agriculture and Natural Resources (LUANAR), University of Pretoria (UP), and Michigan State University (MSU) (2014-2015).

Table 2. Distribution of landholdings and cultivated area by farm size in Malawi, according to the World Bank's 2013 Integrated Household Panel Survey in Malawi. Source: [27].

\begin{tabular}{cccccc}
\hline & \multicolumn{3}{c}{ Landholding Size } & \multirow{2}{*}{ Total } \\
\cline { 2 - 5 } & $\mathbf{0 - 2}$ ha & $\mathbf{2 . 0 0 1 - 5}$ ha & $\mathbf{5 . 0 0 1 - 1 0 ~ h a ~}$ & $>\mathbf{1 0}$ ha & \\
\hline \# of farms & $2,355,461$ & 217,757 & 18,446 & 10,230 & $2,601,893$ \\
\% of total \# of farms & $90.53 \%$ & $8.37 \%$ & $0.71 \%$ & $0.39 \%$ & $100 \%$ \\
Area cultivated (ha) & $1,496,465$ & 567,556 & $113,241.6$ & $776,407.6$ & $2,953,670$ \\
Total landholdings (ha) & $1,693,828$ & $619,700.7$ & $116,838.7$ & $897,553.8$ & $3,327,921$ \\
Mean farm size (ha) & 0.72 & 2.85 & 6.33 & 87.74 & 1.28 \\
Mean ratio of land cultivated to land owned & 0.86 & 0.92 & 0.97 & 0.87 & 0.89 \\
\% of total landholdings & $50.9 \%$ & $18.6 \%$ & $3.5 \%$ & $27.0 \%$ & $100 \%$ \\
\% of total cultivated land & $50.7 \%$ & $19.2 \%$ & $3.8 \%$ & $26.3 \%$ & $100 \%$ \\
\hline
\end{tabular}

Note 1: This table, i.e., the data and classification, is based on the nationally representative 2013 Integrated Household Panel Survey in Malawi, undertaken by the National Statistical Office. These findings may substantially underestimate the amount of land under medium-scale holdings in Malawi. It is well documented that population-based surveys such as the Malawi Integrated Household Panel Surveys and other Living Standards Monitoring Survey (LSMS)-type surveys, tend to under-report relatively large farms compared with census-based approaches for determining farmland ownership [27]. Moreover, the National Statistical Office indicates that the Integrated Household Panel Survey covers farms in customary lands only, and does not include the "Estate Sector," which purportedly contains roughly 30,000 farms encompassing over 1 million ha of land [29]. If this Estate Sector land were added to the ">10 ha" category in Table 1, it would show that roughly 44 percent of Malawi's farm landholdings are controlled by a small proportion of the population, with holdings greater than 10 ha. Note 2: The appendix shows the 2013 Integrated Household Panel Survey for the three selected districts.

From an agro-ecological point of view, the three districts are relatively similar. Falling within a semi-arid to sub-humid climate, production systems combine dryland crop production, often on individual plots (under traditional, leasehold or private ownership), with extensive cattle and small-stock grazing, generally on communal lands. Maize represents the major crop covering, on average, 76 percent of all cultivated land in the three districts. Other food crops include sorghum and millet. Cassava, potato, and sweet potato are also generally planted by small- and medium-scale farmers. The area planted with cassava, and often intercropped with maize, has increased sharply over the past 10 years, particularly in densely populated areas such as around Lilongwe. Kasungu district, on the other hand, is characterized by significant tobacco production as the dominant cash crop, providing 71 percent of export earnings, from the large-scale estate farms as well as from smaller-scale farming sectors [30]. Despite the input subsidy programs, the overall productivity remains low (e.g., average maize productivity is around 1.5 tons/ha). As it is with Malawi overall, the three districts are characterized by high population densities (Lilongwe rural has 216 inhabitants $/ \mathrm{km}^{2}$, Mchinji has 136 inhabitants $/ \mathrm{km}^{2}$ and Kasungu has 80 inhabitants $/ \mathrm{km}^{2}$ ). Farm sizes are thus small, with average sizes of 1.66 ha in Mchinji, 1.32 ha in Kasungu and 1.14 ha in the more populated Lilongwe district. According to government data, the urban and economic dynamics in the Lilongwe region result not only in overall smaller farm sizes on average, they also lead to relatively more significant 
consolidation as the region has proportionally more bigger farms and landholdings (1.10 percent of the total farms and 24.90 percent of the landholdings are bigger than 10 ha, compared with 0.39 percent and 2.63 percent, respectively, in Kasungu). Kasungu, on the other hand, is characterized by a larger number of estate farms [29].

\subsection{Scope, Methods and Limitations}

Our analysis is largely descriptive, in line with our objectives of documenting the changes in land controlled by medium-scale farmers and their defining characteristics. Our focus is on the medium-scale farmers, and we report data on small- and large-scale farmers for comparison purposes only. Emphasis is put, on one hand, on the categorization of medium-scale farmers and, on the other hand, on dynamics and trajectories of farmers and farm entities. We present descriptive statistics and, in some cases, the results of basic statistical tests for between-group comparisons. Some statistical analyses, however, are actually between-group (small-scale and large-scale) and sub-group (medium-scale), no doubt impacting the results of analysis of variance tests, but are included here for comparison purposes. Although this allows for some broader analyses and for empirical findings, we remain cautious about overall generalizations.

Such limitations regarding generalizations are also related to the lack of existing data. The study took into account several logistical challenges with respect to the identification of suitable farm households for the sample. First, none of the selected districts had up-to-date lists containing the sizes of landholdings within their respective jurisdictions. Lists of the population of farms with medium-scale landholdings therefore had to be prepared by Agriculture Extension Development Coordinators (AEDCs) from the Extension Planning Areas (EPAs). Malawi is divided into eight Agricultural Development Divisions (ADD) and 28 districts. The ADDs are further separated into 173 EPAs. Second, there was some confusion regarding the units of measurement, with some farmers and AEDCs mixing hectares with the smaller unit of acres. These challenges and the risks to the validity of the sample were recognized, precipitating the decision to return to all of the surveyed EPAs a few months after the initial survey to acquire the landholding size lists again and cross-check them with the lists used originally. This cross-check process was successful, affirming the integrity of the lists and accuracy of the farm data provided.

\section{Land Policy and the Evolution of Medium and Large Farms in Malawi}

Immediately prior to independence in the early 1960s, roughly 87 percent of Nyasaland's total land area was designated African Trust Land (Nyasaland was a British colony until 1964, when it became the independent Republic of Malawi). Less than 3 percent of the land area was freehold or government leasehold, with most of it being farmed by Europeans. The balance, roughly 10 percent, was public land used for State forest reserves and other public purposes.

Malawi was declared a republic on 6 July 1964, upon which it adopted a new constitution and Dr. Hastings Kamuzu Banda was elected the country's first president. His agricultural vision did not radically contrast with the colonial system, as it was mainly based on the establishment of, and support to, a large-scale farming sector. The main pillars of the rural economy promoted by the Banda regime were production of cash crops for export, and the export of migrant labor. The regime appreciated that the two could be facilitated by providing services of various kinds to commercial agriculture and neglecting traditional subsistence farming so as to reinforce its role as a reservoir of cheap labor [31]. The Banda government sought to transform legal tenure through a declaration in 1965 that economic farming systems were viable only when operated under a sound system of land tenure, based upon security of individual land ownership and negotiability of the title. As such, a portion of customary lands was converted into leaseholds on which more entrepreneurial farmers were provided with incentives and assistance to grow high value crops, especially tobacco [31]. The newly established estates had the further advantage of cheap finance collateralized by land acquired from 
smallholder farmers through acquisition of customary lands. Stambuli [32] observes that the estates also benefited from low interest rates and a favorable land tax regime.

Building on colonial development thinking, Dr. Banda fostered the creation of an elite class of Malawians that he thought would spearhead agricultural development and national growth, while excluding those individuals deemed to be less productive. Through this philosophy, the Agricultural Development and Marketing Corporation (ADMARC) "taxed" smallholder farmers through its pricing policies and used that income to promote estate farming for export [33]. Furthermore, because customary land was transferred to estates, credit to adopt improved technologies was less available to smallholders [32]. Soon, the term mchikumbe, meaning "master farmers", was being used to label the few farmers whose performance was approved of by the government extension workers, just as the case was in colonial days. Those classified as mchikumbe had easy access to loans for farm improvements, thereby reinforcing the advancement of these farmers.

During Dr. Banda's era, about a million hectares of land were converted to leasehold. This was land appropriated from customary land held by (or in reserve for) local smallholder farmers under the custodianship of local chiefs. Other advantages extended to estates included licenses to grow and sell burley tobacco (a privilege denied to smallholder farmers on grounds of technical incapacity, a need to control quality and prices, and its environmental impact), extension services, credit and marketing support. Such privileges were provided by the Ministry of Agriculture, the commercial banks, and ADMARC [31,32]. State bureaucrats, Members of Parliament (MPs) and party functionaries topped the list of beneficiaries. At the same time, senior civil servants were encouraged to go into commercial farming. Beneficiaries straddling the rural-urban divide moved profits from farming into urban real estate, retail trading and transportation.

Commack et al. [31] observe that the Structural Adjustment Programs implemented under pressure from the International Monetary Fund (IMF) and World Bank in the 1980s significantly disrupted the ways in which the system for channeling rents had worked under Dr. Banda. The IMF and World Bank policy of reforming the estate sector to reduce subsidies and make it more competitive, together with the shift against import-substitution industrialization, constrained the types of rent-creation and distribution that were formerly encouraged. As a result, inflation took hold. These and other economic factors had an impact on politics throughout the 1980s, resulting in dissent arising against Dr. Banda's regime from around 1991.

After the ousting of Dr. Banda during the multiparty elections of June 1994, the focus of economic growth and development shifted more towards small-scale businesses, the promotion of the informal sector of the economy and smallholder agriculture. With regard to the agricultural sector, firstly, the United Democratic Front (UDF)-led government introduced several agricultural programs, such as the Starter Park Program and drought mitigation programs, together with the encouragement of non-maize food crops. It was also under the UDF government that the Malawi National Land Policy was formulated in 2002. Among its key recommendations, the Land Policy sought to allow all customary land to be registered and protected by law against arbitrary conversion to public land. Furthermore, the traditional supervisory role of chiefs, clan leaders, headpersons and family heads in land matters was to be formalized and streamlined to allow uniform administrative procedures and transparency in all customary land transactions. Moreover, the policy stipulated numerous tenure system reforms, new rights for women, freezes on the amount of freehold land in Malawi owned by non-citizens, and prohibitions on the right of non-citizens to acquire title to new freehold estates [34].

Thereafter, the Democratic Progressive Party (DPP) regime of Bingu wa Mutharika and Bakili Muluzi (1994-2005) did not bring any revolutionary changes in land matters, but did implement several highly popular agricultural initiatives, most prominently the Farm Inputs Subsidy Program. During the Mutharika period, however, Malawi witnessed a spate of new land acquisitions from customary landholdings, primarily for the benefit of both foreigners and local elites. Chikaipa [35] observes that local communities, with support from civil society actors, have bemoaned and resisted most of the attempts on land grabs, but that government has remained "willfully" deaf, ignoring such 
concerns. Chikaipa [35] further notes that it is on record that no transaction has at any occasion been cancelled or put on hold due to the public outrage over the land acquisitions. Chikaipa [35] argues that as long as the power relationship between the state and local communities in the battle against land acquisitions is not equal, the resistance and opposition from the local communities and civil society actors are not enough to successfully thwart the land deal transactions.

This policy favoring land conversions from customary to titled land seems to be pursued by the current president, Peter Mutharika, the former president's brother. Although his track record with regard to land issues is not yet evident, he appears to be pursuing similar development strategies, with a few exceptions in terms of restructuring the public service operational framework. The Peter Mutharika administration does recognize the many challenges on land matters and has stated an intent to advocate for the enactment of all land-related Bills that are submitted to Parliament, and to conduct comprehensive public awareness campaigns on existing land laws.

The above agricultural political economy has had significant impact on the country's present agricultural and farm structures. As such, the most recent nationally representative survey of rural households shows that 30.5 percent and 30.1 percent of the total landholdings and area under cultivation are in the hands of one percent of the nation's farmers, who control five or more hectares of land (Table 2, $[27,28])$. The vast majority of farmland in this category is controlled by people holding over 10 ha of land.

\section{Characteristics of Medium-Scale Farmers in Malawi}

The medium-scale farmers of the three districts examined in this study predominantly occupy, lease or own 5 to 10 ha. They account for 65 percent of the total sample, with farms on landholdings of 10 to 20 ha accounting for 28 percent (Figure 1). This distribution varies significantly according to district however. Although the distribution among districts is similar for the 5 to 10 ha farm size category, Kasungu has the bigger farms, from 10 ha upwards. This is related to the estate development policy that the Government of Malawi implemented particularly in that region. On the other hand, Lilongwe is the district with, on average, the smallest landholdings. The latter is directly related to land pressures in higher population density areas [32,36] (Figure 2).

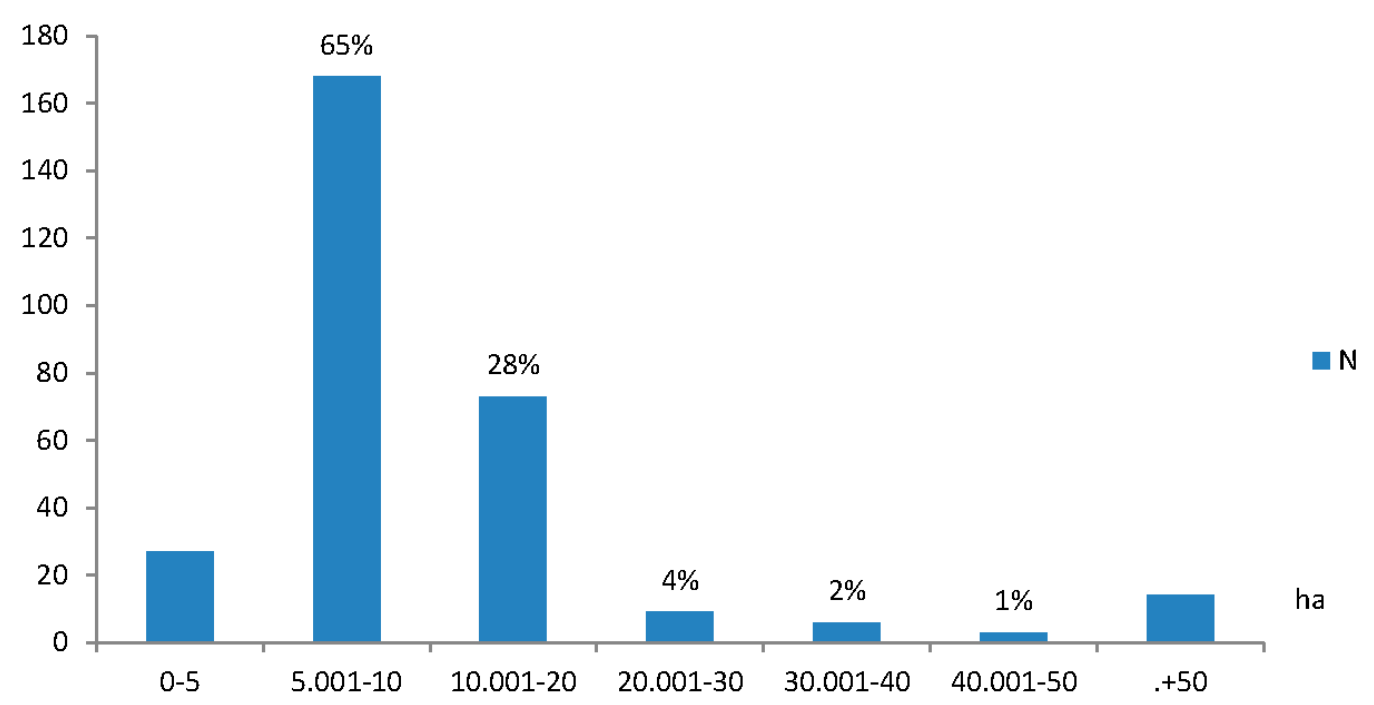

Figure 1. Numbers of medium-scale farmers sampled in Mchinji, Kasungu and Lilongwe, by farm size category (ha) $(N=300)$. Source: Authors' medium-scale farm survey in Mchinji, Kasungu and Lilongwe Districts undertaken by LUANAR, UP, and MSU (2014-2015). Notes: The percentages represent the proportion of farms in each of the categories of medium-scale farmers in the sample $(N=259)$. The number of farmers in the different land categories between 5 and 50 ha are significantly different (Anova $p$-value $2.84 \times 10^{-88}$ ). 

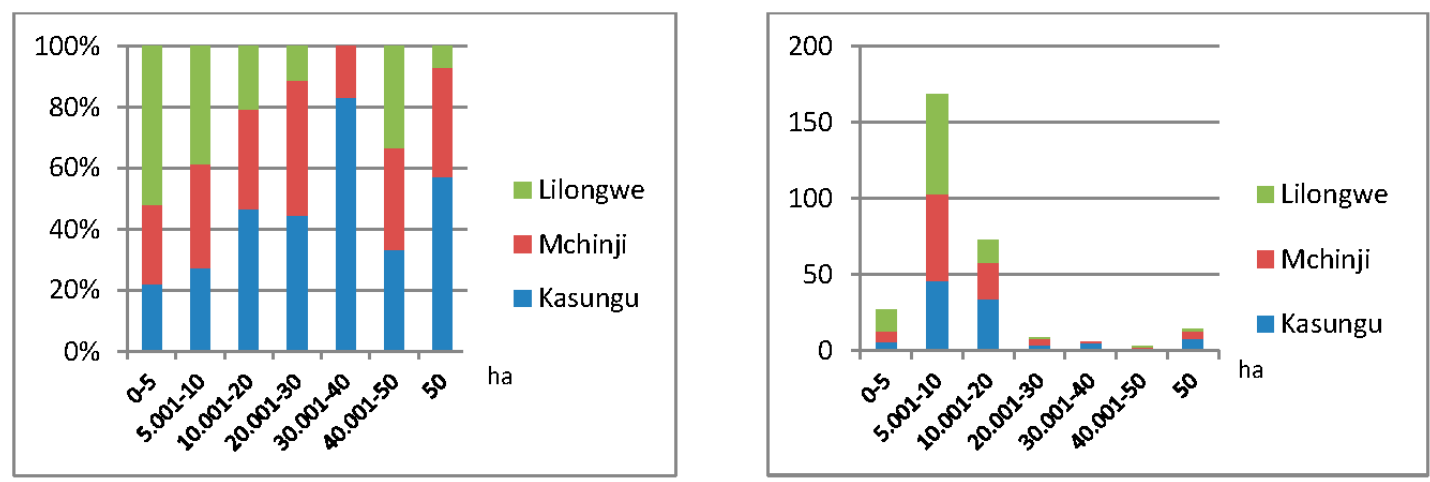

Figure 2. Numbers of medium-scale farmers sampled, per size category and per district, proportionally per size category and in absolute numbers per size category $(N=300)$. Source: Authors' medium-scale farm survey in the Mchinji, Kasungu and Lilongwe Districts undertaken by LUANAR, UP, and MSU (2014-2015). Note: There is a statistically significant difference in size categories between Lilongwe, Mchinji and Kasungu (Anova $p$-value $2.90 \times 10^{-41}$ ).

A large proportion of sampled farmers are part-time farmers, for whom farming is not a primary source of income and who, in general, do not reside on the farms. The latter amount to 40.2 percent of the total sampled farmers. This proportion rises with landholding size; it even reaches 69.2 percent of the +50 ha farms. Figure 3 shows a clear (positive) correlation between the sizes of the farms, owners primarily living elsewhere, and the origin of income used to acquire the farm. Land accumulation and medium-scale farm dynamics are thus certainly related to self-financing with non-farm income $[7,20]$. However, it would be inappropriate to conclude that these land dynamics are purely led by relatively wealthy, urban-based, segments of society: Most of the smaller sized, medium-scale holdings are indeed held by resident farmers, many of whom financed their land using income from farming. In fact, farming was the primary source of income for 59 percent (154) of the sampled farmers, but even among this group, 81.4 percent of them reported having had one or more jobs/incomes outside of agriculture at an earlier point in their lives (Table 3). This probably explains the relatively high age of the farmers and/or the relatively higher proportion of bigger farm owners who have a background, or whose father has a background, in the public sector (Tables 3 and 4).

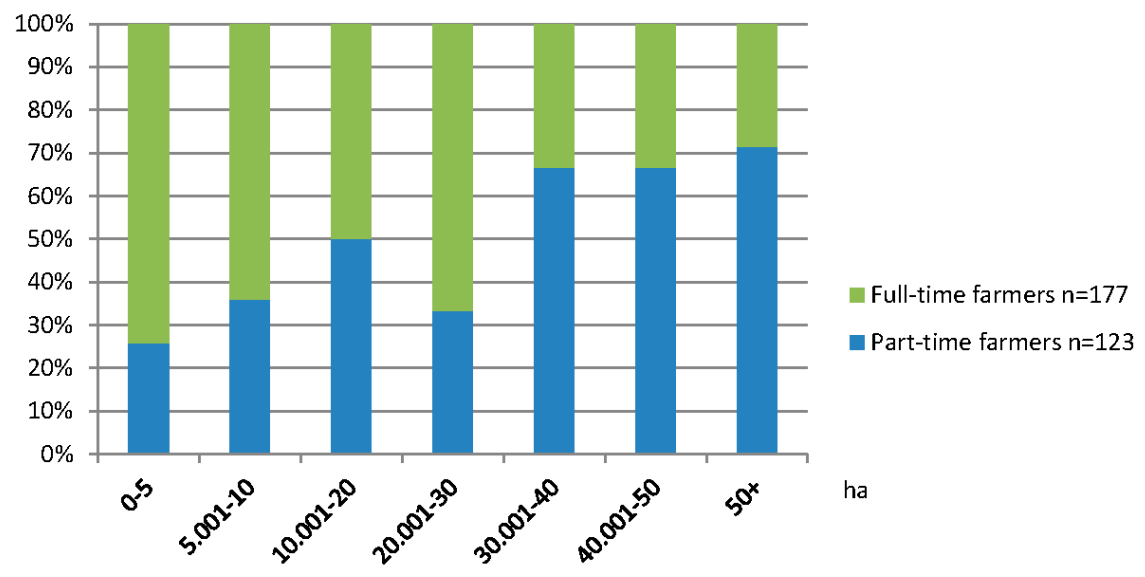

Figure 3. Percentage of full-time and part-time farmers, by farm size, in Mchinji, Lilongwe and Kasungu $(N=300)$. Source: Authors' medium-scale farm survey in the Mchinji, Kasungu and Lilongwe Districts undertaken by LUANAR, UP, and MSU (2014-2015). Note: There is a statistically significant difference in the distribution by land size between full-time and part-time farmers at a $5 \%$ level of significance (Anova $p$-value 0.021747). 
Table 3. Multiple revenue sources of sampled medium-scale farmers * in Mchinji, Lilongwe and Kasungu. Source: Authors' medium-scale farm survey in the Mchinji, Kasungu and Lilongwe Districts undertaken by LUANAR, UP, and MSU (2014-2015).

\begin{tabular}{|c|c|c|c|c|c|}
\hline & & \multirow[b]{2}{*}{$\begin{array}{l}\text { Small-Scale }(0-5 \text { ha }) \\
\qquad(N=27)\end{array}$} & \multicolumn{2}{|c|}{ Medium-Scale (5.001-50 ha) $(N=259)$} & \multirow[b]{2}{*}{$\begin{array}{l}\text { Large-Scale }(+50 \text { ha }) \\
(N=14)\end{array}$} \\
\hline & & & $\begin{array}{l}\text { Full-Time Farmers: Farming } \\
\text { as Longstanding Primary } \\
\text { Source of Income }\end{array}$ & $\begin{array}{l}\text { Part-Time Farmers: Farming } \\
\text { Not as Longstanding Primary } \\
\text { Source of Income }\end{array}$ & \\
\hline \multicolumn{2}{|l|}{ Farmers $N$} & 27 & 154 & 105 & 14 \\
\hline \multicolumn{2}{|c|}{$\%$ who have salaried jobs/regular income outside of farming } & 22.22 & 40.4 & 100.0 & 64.28 \\
\hline \multicolumn{2}{|c|}{$\begin{array}{l}\% \text { who have never had a salaried job or regular income } \\
\text { outside agriculture }\end{array}$} & 74.1 & 18.7 & 0.0 & 30.8 \\
\hline \multicolumn{2}{|c|}{$\%$ who are public sector employees } & 16.7 & 17.3 & 18.8 & 11.1 \\
\hline \multirow{2}{*}{$\begin{array}{l}\text { Father of household head's } \\
\text { primary occupation }\end{array}$} & $\%$ in public sector & 0 & 3.2 & 7.7 & 7.7 \\
\hline & $\%$ in salaried private sector jobs & 3.7 & 5.2 & 13.5 & 15.4 \\
\hline
\end{tabular}

Note 1: Part-time farmers (Figure 2 and Table 3) are defined here as not residing full-time on farm and as having multiple income sources, with farming not being a longstanding primary income source. Note 2: * Data for small-scale and large-scale farmers are presented here for comparison purposes.

Table 4. Farm characteristics by farm size $(N=300)$. Source: Authors' medium-scale farm survey in the Mchinji, Kasungu and Lilongwe Districts undertaken by LUANAR, UP, and MSU (2014-2015).

\begin{tabular}{|c|c|c|c|c|c|c|c|}
\hline & \multicolumn{7}{|c|}{ Farm Sizes (ha) } \\
\hline & $0-5$ & $5.001-10$ & $10.001-20$ & $20.001-30$ & $30.001-40$ & $40.001-50$ & +50 \\
\hline Farmer/manager is family member $(\%)$ & 85.2 & 86.3 & 84.9 & 88.9 & 66.7 & 66.7 & 78.6 \\
\hline Average age of farmers (St. dev.) & $54(9.10)$ & $53(14.07)$ & 55 (12.55) & $58(12.63)$ & $55(8.18)$ & $50(9.89)$ & $52(12.86)$ \\
\hline Average ratio cultivated to total landholding * (St. dev.) & $1.019(0.99)$ & $0.791(0.31)$ & $0.589(0.33)$ & $0.443(0.33)$ & $0.329(0.24)$ & $0.412(0.41)$ & $0.412(0.31)$ \\
\hline Average number of family laborers (St. dev.) & $4(1.73)$ & $4(2.27)$ & $4(2.69)$ & $3(2.78)$ & $2(1.60)$ & $2(1.53)$ & $2(1.83)$ \\
\hline Average number of non-family full-time laborers (St. dev.) & $0(0.70)$ & $2(0.70)$ & $4(5.02)$ & $6(4.86)$ & $6(1.73)$ & $4(4.62)$ & $25(44.06)$ \\
\hline Average number of non-family temporary seasonal laborers (St. dev.) & $10(10.82)$ & $10(8.34)$ & 16 (19.83) & $12(9.81)$ & $17(8.37)$ & $73(115.63)$ & $29(77.68)$ \\
\hline Farmers with tractors & 0 & 0 & 0 & 0 & 0 & 0 & 5 \\
\hline
\end{tabular}

Note: * Plots cultivated twice per year and rented land are included in the computation, which explains why the ratio exceeds 1 for the $0-5$ ha category. 
Overall, the large majority of medium-scale farmers in the sample, and especially the bigger ones, have or have had salaried jobs outside of agriculture or regular non-farm income. The situation thus has to be nuanced. The larger medium-scale farms have developed production systems effectively based on pluri-activity and multiple income sources, where the farmer is non-farm based, inducing an externally led development pattern through non-farm funds. The smaller medium-scale farmers (5-20 ha), on the other hand, although also significantly engaged in non-farm activities, seem to develop such strategies as a necessity to diversify in order to accumulate.

Income diversification also has significant consequences with regard to the production models developed across the full set of sampled farms, including the small- and large-scale comparison groups. Indeed, the lower farm size groups develop production models based on family farms, whereas the majority of the farms with more than 30 ha are of a more entrepreneurial nature. The former are mainly based on family labor, although they also do employ, on average, two to six full-time non-family laborers, as well as 10 to 16 seasonal laborers. The ratio of family labor to hired labor for the smaller farms varies between 1 per 2.5 and 1 per 5 . The bigger farms, by contrast, are often run by non-family managers and the overall labor force is more dependent on non-family members. The family labor to hired labor ratio for the bigger farms decreases to 1 per 36. From a labor creation per ha point of view, in the survey, the number of full-time and temporary people employed per hectare of landholding is roughly 2 for farms under 20 ha and 1.2 for landholdings over 30 ha, suggesting a higher per land unit use of hired labor for smaller farms. Table 4 shows other distinctions between these two models.

Patterns of cultivation and productivity also vary by landholding size for the sampled farms. Based on the sampled farms in the three districts, the ratio of cultivated land to landholding size declines sharply with total landholding (Figure 4$)$. For smallholder farmers ( $0-5 \mathrm{ha})$, this ratio is even higher than 1 (related to renting land and the use of multiple cycles on the same plot), indicating the degree of land pressure experienced by this category of farmers. This ratio falls to about 40 percent for the farms larger than $30 \mathrm{ha}$. These results show a decrease in land utilization as landholding size rises. The latter is also the case when the net value of crop output per hectare cultivated is measured. This measure of land productivity is the highest, on average, for sampled farms between 10 ha and 20 ha, decreasing for higher sizes, although there is great variability in net value of crop output per hectare cultivated at all levels of landholding size (Figure 5).

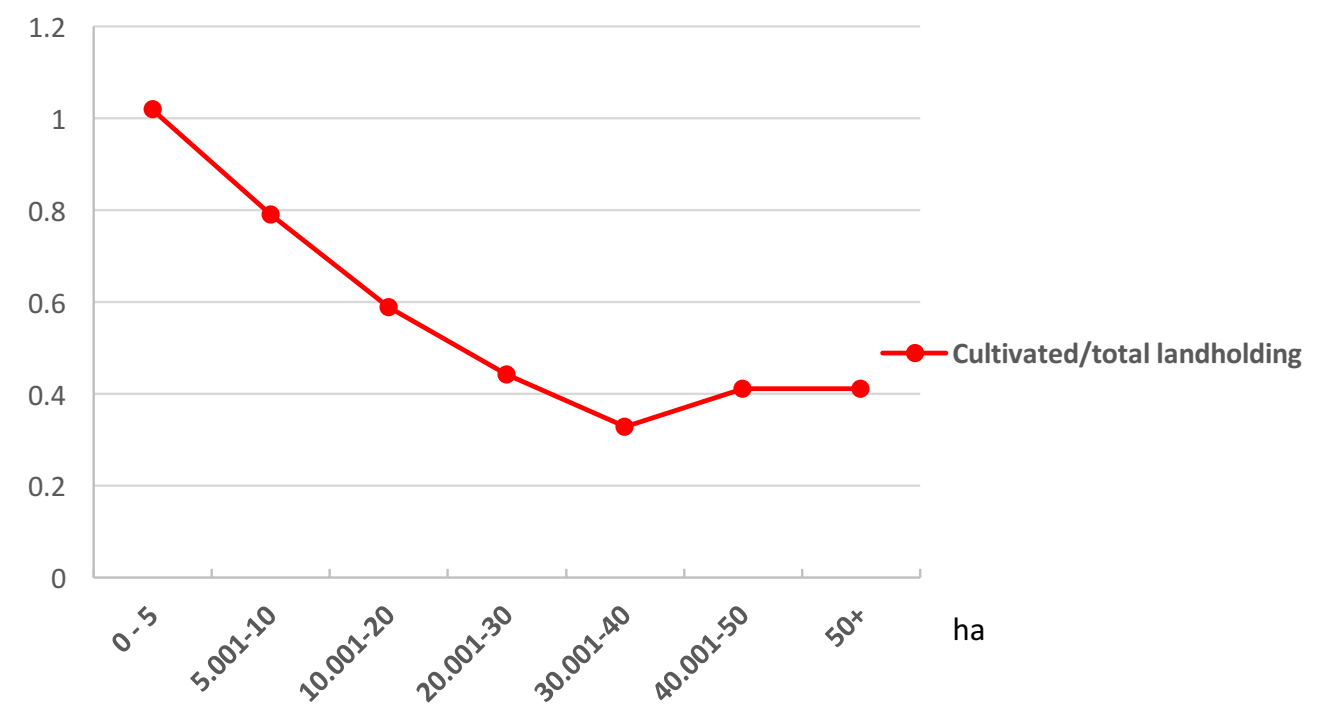

Figure 4. Cultivated land vs. total landholding ratio for the different farm size categories $(N=300)$. Source: Authors' medium-scale farm survey in the Mchinji, Kasungu and Lilongwe Districts undertaken by LUANAR, UP, and MSU (2014-2015). Note: The ratios of cultivated land to total landholding among the different land categories is statistically significant at a $5 \%$ level of significance (Anova $p$-value $2.14 \times 10^{-46}$ ). 


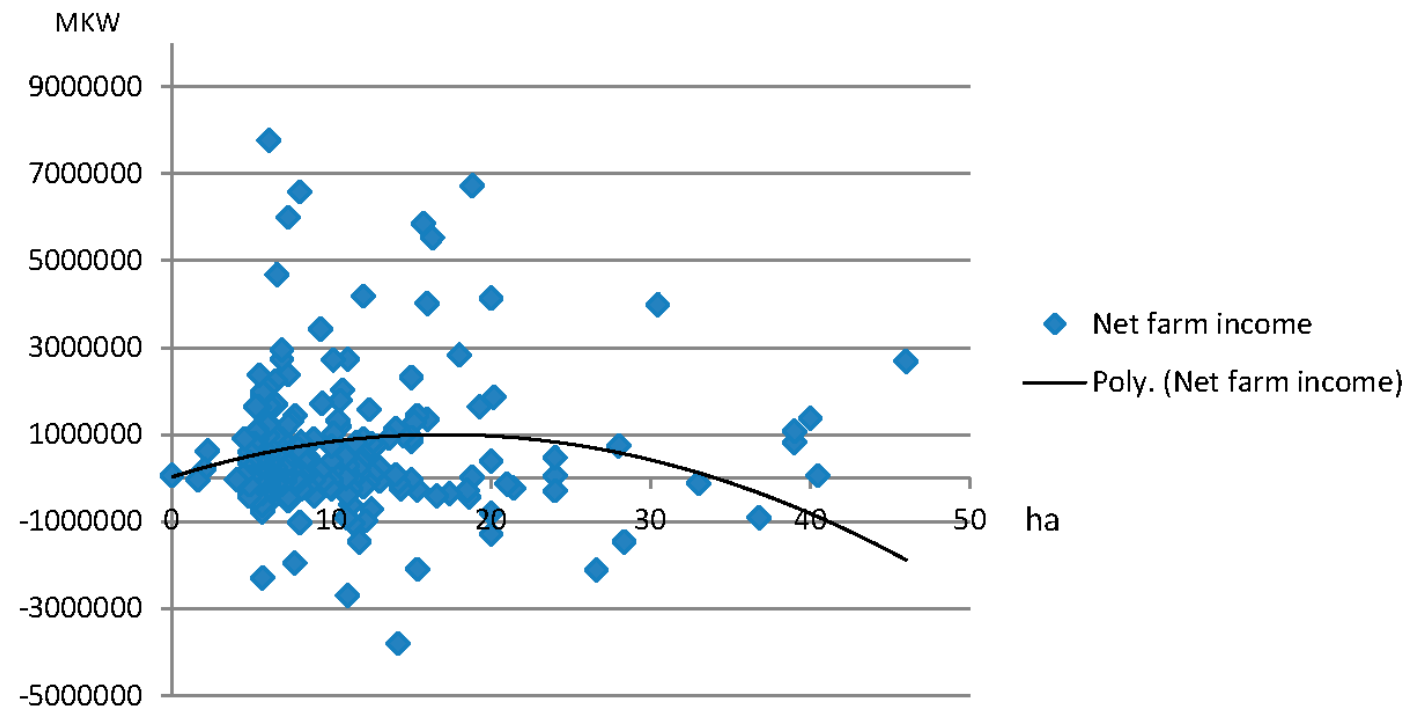

Figure 5. Productivity (net farm income) per hectare for the different sizes of farms $(N=300)$. Source: Authors' medium-scale farm survey in the Mchinji, Kasungu and Lilongwe Districts undertaken by LUANAR, UP, and MSU (2014-2015).

\section{Farmland Ownership Dynamics}

\subsection{Rising Land Acquisitions of Medium-Scale Farmland}

Figure 6 shows that the land under medium-scale holdings in the sample in the three districts has almost doubled between 2000 and 2015, from 2544 ha in 2000 to 4726 ha in 2015. As the reverse trend of medium-scale farmers becoming small-scale ones has not been identified during the survey and is rather unlikely (since it would entail a conversion of leasehold/private land back to traditional customary land) and as the origin of the present medium-scale farmers and their land is accounted for in this study (either conversion of traditional customary land or transfer from small- and medium-scale leasehold/private land to medium-scale farmers), it can be estimated that, just over the past decade since 2005, the land under medium-scale holdings has increased by 49.1 percent. If our sample in these three districts can be extrapolated to the whole of Malawi based on Table 2, we can conclude that roughly 300,000 ha have been newly acquired by medium/large-scale holders since 2005, slightly less than 10 percent of the total area of landholdings in Malawi. The rapid rise in medium-scale farms over the past decade is truly remarkable in a country where the majority of rural people face acute land scarcity and where household poverty is highly correlated with very small farm size [27].

Moreover, given our finding that 39 percent of the sampled medium-scale farms (and 48 percent of the land) are controlled by people primarily residing in urban areas, a significant portion of the farmland in the "over 10 hectare" category of Table 1 could be controlled by part-time farmers living in urban areas. If 48 percent of the 776,000 ha of customary land under cultivation on landholdings over 10 ha were controlled by urban-based households, this would imply that roughly 12.6 percent of the area under cultivation in customary lands is producing revenue that is generated in rural areas, but is spent by people living primarily in urban areas. Such estimates may rise further when considering the estate farm sector. This kind of farmland ownership structure implies that the multiplier effects of agricultural growth may therefore not be confined to rural areas; a significant portion of revenue from agriculture, and from subsequent expenditure and employment effects, may occur in urban areas. A better understanding of the relationship between surplus agricultural production and the location of expenditures from it may allow policy makers to anticipate how default patterns of land acquisition are affecting where the multiplier effects of agricultural growth are likely to occur. 


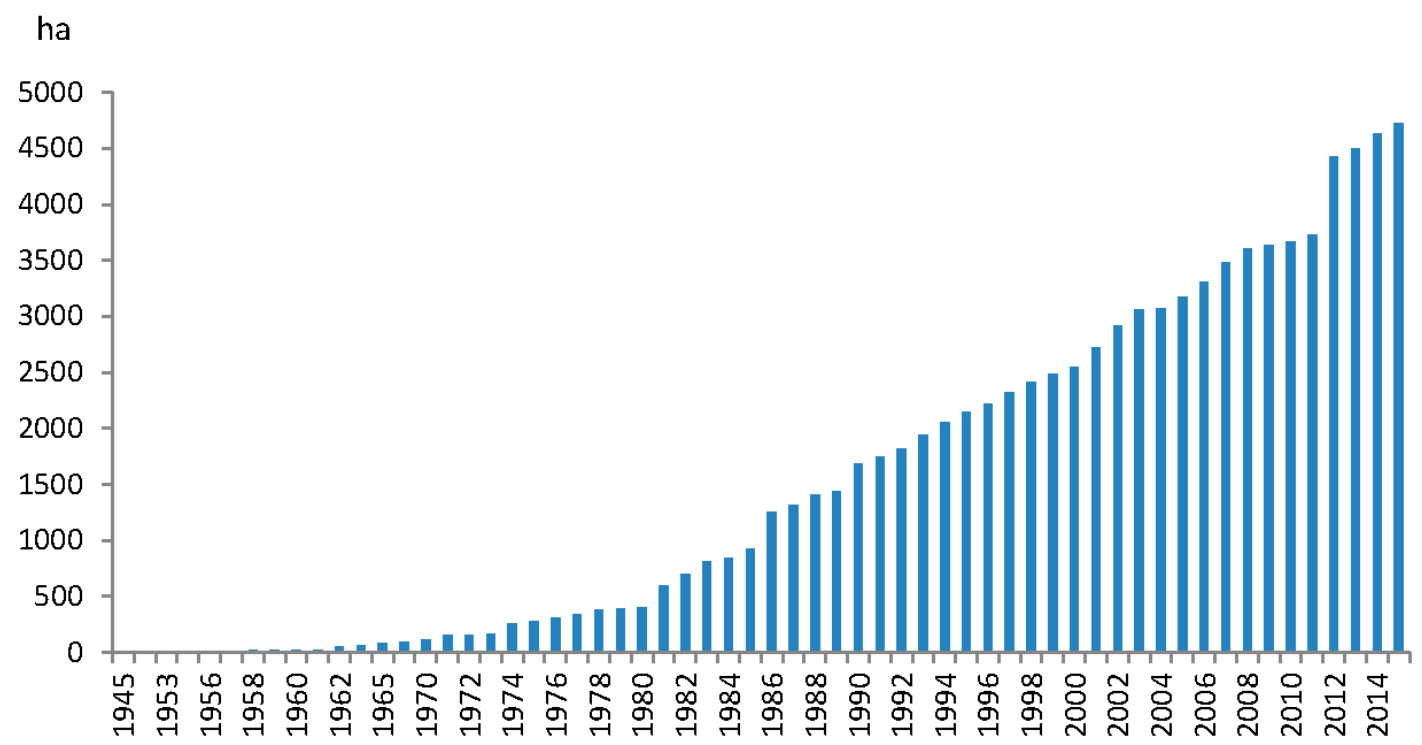

Figure 6. Cumulative land acquisitions by medium-scale holdings among sampled farms $(N=300)$ in the Mchinji, Kasungu and Lilongwe Districts (ha per year). Source: Authors' medium-scale farm survey in the Mchinji, Kasungu and Lilongwe Districts undertaken by LUANAR, UP, and MSU (2014-2015).

A very similar trend is occurring with field-level land acquisitions; they are also rapidly increasing. Among the 300 sampled farms, there were 89 field acquisitions that occurred before 1980; 272 fields were acquired between 1980 and 2000, and 211 fields were acquired since 2000. Interestingly, aside from the large-scale farms acquisitions (of which 50 percent represent acquisitions by a company, 31 percent by part-time farmers and 18 percent by full-time farmers), the large majority of the acquisitions are by private individuals. Their total landholding grew, on average, by 8 ha, representing an increase of 449 percent (Table 5). A significant increase in the size of acquisitions occurs after 2011. Although here, again, the large majority of acquirers were full-time farmers (66 percent of the acquisitions, with 31 percent being part-time farmers), with the major difference of one company acquiring 493 ha, illustrating the renewed interest in farmland since the rise in global food prices after 2008 (Figure 7).

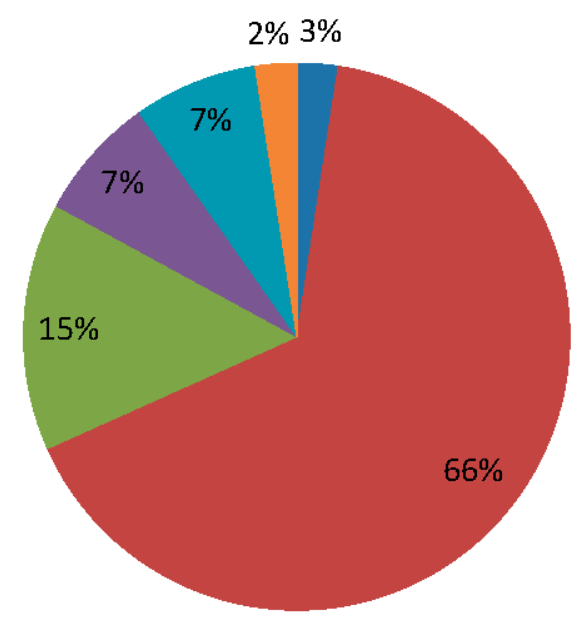

\author{
- Companies/corporate entities \\ Fulltime farmers \\ - Currently employed (no additional \\ info available) \\ Public sector \\ Private sector \\ Self employed non-agricultural \\ sector
}

Figure 7. Land acquisitions, 2011-2014 $(N=300)$. Source: Authors' medium-scale farm survey in the Mchinji, Kasungu and Lilongwe Districts undertaken by LUANAR, UP, and MSU (2014-2015). Note: Land acquisitions include lease deals and customary land. 
Table 5. Evolution of sampled medium-scale farmers' * landholding size, in Mchinji, Kasungu and Lilongwe.

\begin{tabular}{|c|c|c|c|c|}
\hline \multirow{2}{*}{ Household Land } & \multirow{2}{*}{$\begin{array}{l}0-5 \text { ha } \\
(N=27)\end{array}$} & \multicolumn{2}{|c|}{$5.001-50$ ha $(N=259)$} & \multirow{2}{*}{+50 ha $(N=14)$} \\
\hline & & Full-Time Farmers & Part-Time Farmers & \\
\hline $\begin{array}{c}\text { Average initial landholding } \\
\text { size at time of formation (ha) } \\
\text { (St. dev) }\end{array}$ & $2.57(4.25)$ & $1.76(9.67)$ & $5.51(9.14)$ & $6.27(14.71)$ \\
\hline $\begin{array}{l}\text { Average current landholding } \\
\text { size (ha) (St. dev.) }\end{array}$ & $4.25(1.33)$ & $9.67(6.35)$ & $11.21(8.20)$ & $135.33(131.12)$ \\
\hline Difference (\%) & +65.37 & +449.43 & +103.45 & +2058.37 \\
\hline
\end{tabular}

These findings suggest that farmland ownership may be changing quite rapidly, at least on the basis of the three districts surveyed. Although the 5-10 hectare group is still the most significant category, the larger farms are rapidly increasing in number (Figure 8). This increase is particularly notable for the larger medium-scale farms.

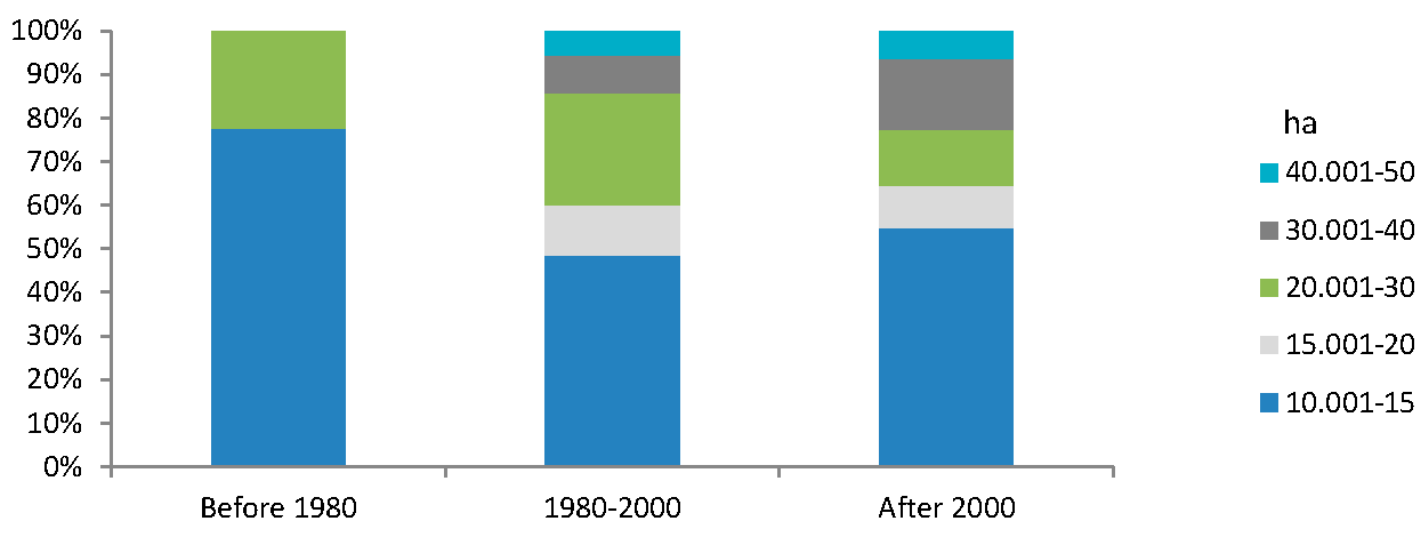

Figure 8. Increasing size of medium-scale landholdings in Mchinji, Kasungu, and Lilongwe $(N=91)$. Source: Authors' medium-scale farm survey in the Mchinji, Kasungu and Lilongwe Districts undertaken by LUANAR, UP, and MSU (2014-2015).

\subsection{Former Use of the Land Acquired by Medium-Scale Farmers}

The large majority of the land acquired by the sampled farmers over time is customary land formerly under the control of traditional authorities. This means that the rise of medium-scale farms is taking place on lands ostensibly reserved as a birthright for local subjects of the traditional authorities in the area. According to the survey respondents, just less than 40 percent of the customary land acquired by medium-scale farmers had been utilized by others prior to the acquisition. However, both the amount and proportion of land acquired by medium-scale farmers that was formerly customary land utilized by others has increased significantly in recent years (Figure 9). The high proportion of land acquired from formerly utilized customary land raises concerns about the possibility that some medium-scale farms are forming as part of a process of disenfranchisement of local rural people from land that was traditionally reserved for them (Figure 10).

After being acquired by the medium-scale farmer, much of the land is successfully converted by the owner to privately held land (Figure 11). The rise of medium-scale farms in the selected three districts of Malawi is associated with a transfer of land from customary tenure to state land. Such land transfers involve the tacit or explicit consent of those administering Malawi's customary and state 
lands. Most farmland acquisitions have followed a general pattern, whereby the potential investor approaches the local headman in his area, as well as the village chief/headman; after agreeing on terms, the traditional authority (usually the chief of the area) signs a consent form that essentially provides the traditional authority's blessings to transfer the designated land from customary to state tenure (and implicitly to privately held land). Thereafter, the farmer may succeed in acquiring a state title deed for a 99-year lease after the land has been surveyed and the owner pays the necessary fees. The leased land is officially state-owned land. These results raise questions as to whether the traditional and/or state institutions of land allocation in customary tenure areas may in some ways be distributionally regressive, transferring large quantities of land out of customary tenure (ostensibly for use by local smallholder residents), often to relatively wealthy landowners holding title deeds under long-term leaseholds. This is a question for further inquiry with potentially important implications for development in Malawi.

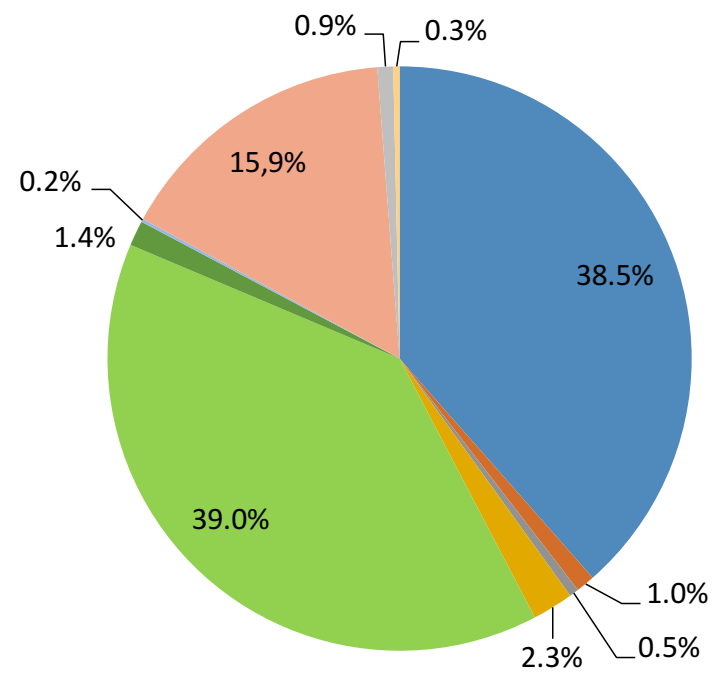

- Unused customary land
- Unused estate land
- Unused public land
- Unused private land
- Used customary land
- Used estate land
- Used public land
Used private land
Forest land
Other

Figure 9. Prior land use and land tenure of lands acquired by medium-scale farms, Kasungu, Lilongwe, and Mchinji districts (in percentage) $(N=300)$. Source: Authors' medium-scale farm survey in the Mchinji, Kasungu and Lilongwe Districts undertaken by LUANAR, UP, and MSU (2014-2015).
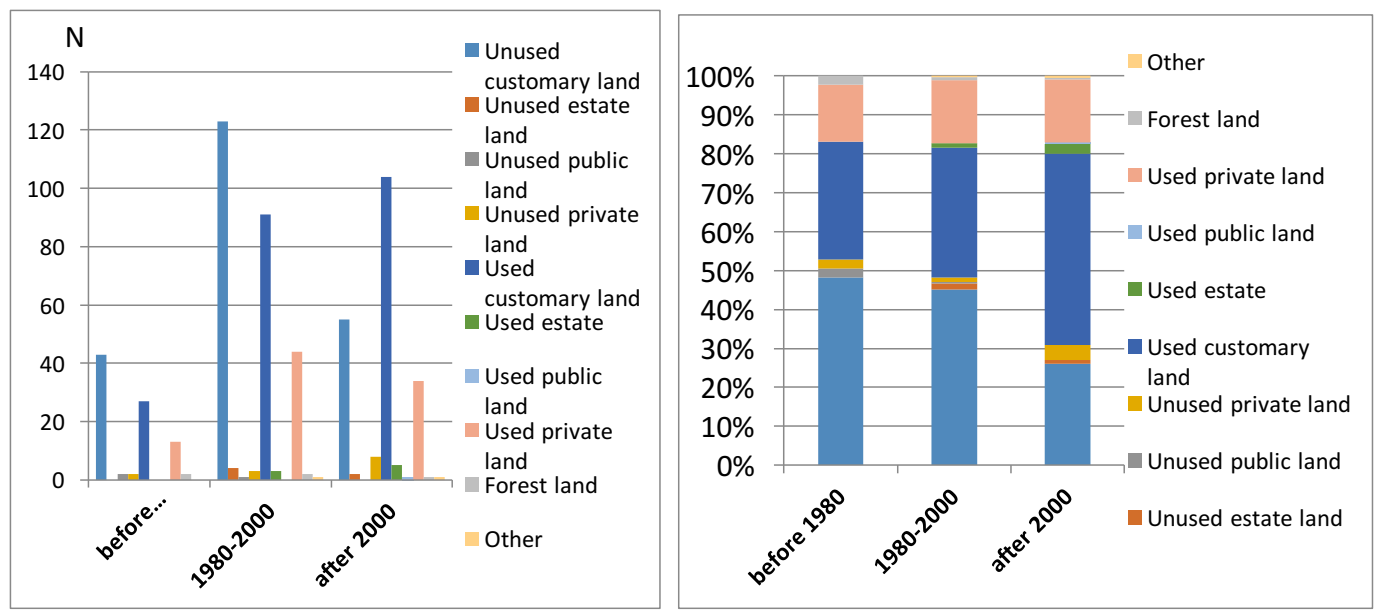

Figure 10. Types of land acquired and their evolution over time, in absolute terms and in percentages of cases $(N=300)$. Source: Authors' medium-scale farm survey in the Mchinji, Kasungu and Lilongwe Districts undertaken by LUANAR, UP, and MSU (2014-2015). 
Although this process of tenure conversion has been promoted more or less actively by prior government regimes as described in Section 2 and might be associated with some form of economic transformation, the findings presented here highlight the point that a land commodification process is underway, whereby the stock of land under customary tenure systems is declining, the stock of land under freehold and leasehold tenure is rising, and land transactions are becoming more common.
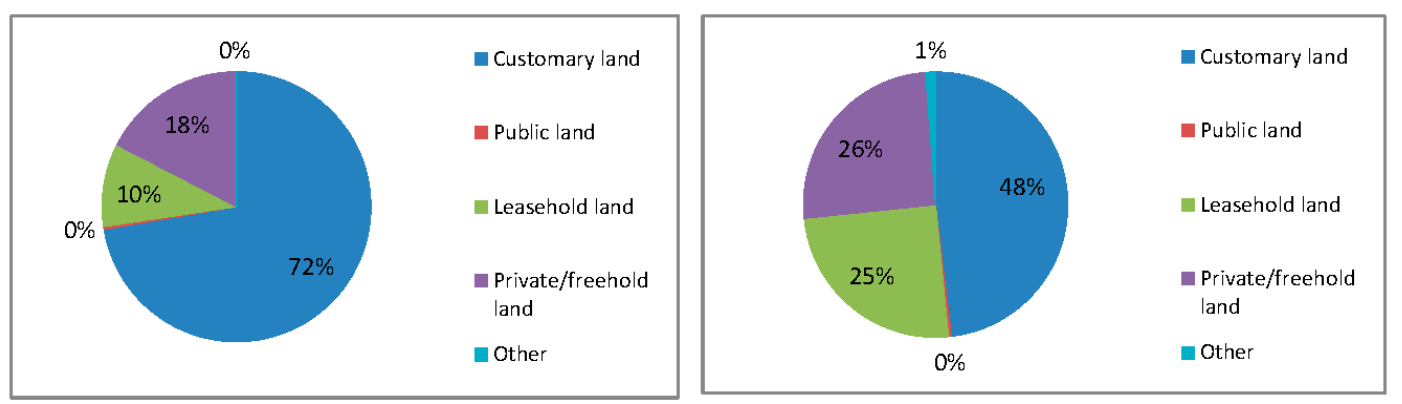

Figure 11. Tenure of the land when acquired (left) and after acquisition (right) (in percentages of number of cases $(N=300)$. Source: Authors' medium-scale farm survey in the Mchinji, Kasungu and Lilongwe Districts undertaken by LUANAR, UP, and MSU (2014-2015).

\section{Discussion}

This study is motivated by the apparent revolutionary changes in the control of African farmland associated with the rise of medium-scale farms. Recent global policy attention to "land grabs" by international investors, while important in some countries, may have diverted attention away from even more rapid land acquisitions by national investors.

A recent study [7] shows a rapid rate of growth of medium-scale farms in three countries, but two of these, Zambia and northern Ghana, contain vast areas of unutilized or underutilized lands where new entrants could begin farming without necessarily dispossessing local people. Malawi is an interesting and important contrasting country where most of its farming population faces land scarcity and where small farm size is an obvious constraint on their livelihoods [27]. The Malawian government's existing strategies are officially intended to promote agricultural growth and food security for its 2.5 million or more small-scale farm households [36]. However, there are increasing concerns that both traditional and state land institutions have encouraged, and may be continuing to encourage, the transfer of land to non-local interests without due cognizance of how this is affecting the land access and food security conditions of current and future generations of rural people. A contrasting view is that medium-scale farms represent one of the few forms of economic dynamism and employment creation in Malawi's rural areas, are more productive users of land, are part of the farm consolidation process that normally accompanies economic development, and hence should be promoted. We reconsider these contrasting narratives after summarizing the main findings of the study.

The study highlights six findings. First, the recent pace of farmland acquisitions in the 5-50 hectare category in Malawi indicates that a relatively quiet but fundamental change in farmland ownership is underway. Though they constitute less than one percent of all farms, official government data indicate that farms over 5 ha now account for roughly 30 percent of the landholdings and area under cultivation in Malawi [27]. Almost 90 percent of this land is controlled by farms over 10 ha, with a mean farm size of $87 \mathrm{ha}$. The share of farmland under the control of medium/large farms would undoubtedly be significantly higher after accounting for Malawi's "estate" farm sector.

Second, in the three districts covered by our survey, the number of medium-scale farms appears to be growing rapidly. Land acquired by medium-scale holdings in the three districts of our study has almost doubled between 2000 and 2015. Over the past decade since 2005, land under medium-scale holdings has increased by 49.1 percent. If our sample in these three districts can be extrapolated 
to the whole of Malawi, we can conclude that roughly 300,000 ha has been newly acquired by medium/large-scale holders since 2005, slightly more than 10 percent of the total area under cultivation in Malawi's customary lands [27]. The rapid rise in medium-scale farms over the past decade is truly remarkable in a country where the majority of rural people face acute land scarcity and where household poverty is highly correlated with very small farm size.

Third, the vast majority of these medium-scale landholdings in the three case study districts are owned by Malawian African nationals. Over 39 percent of them were not primarily involved in farming prior to acquiring their farms. Even among the remaining 61 percent of medium-scale farmers, the prevalence of salaried employees in non-farm jobs is substantially higher than the average found within Malawi's small-scale farming sector. Approximately 40 percent of the sampled farms were owned by part-time farmers living in urban areas and hiring a manager to handle daily activities. Therefore, a significant portion of the revenue earned from agriculture, while generated in rural areas, may be spent in urban areas, contributing the multiplier and employment effects there and weakening such effects in rural areas.

Fourth, the rise of medium-scale farms in the selected three districts of Malawi is in most cases associated with a transfer of land from customary tenure to public land. Many of the medium-scale farmers ( 25 percent) sampled in the three districts held title deeds with long-term leases. Such land transfers involve the tacit or explicit consent of those administering Malawi's customary and state land institutions. Given that land scarcity within many of Malawi's customary tenure areas appears to be a serious problem [31], the removal of land from the customary tenure system, where traditionally it would have been reserved for local community use, into state-owned land may have potentially important implications for Malawi's most important development objectives such as food security and poverty alleviation-implications which are as yet not fully clear.

Fifth, over the entire sample, 38 percent of the respondents indicated that the lands on which their farms are located were formerly utilized by others in the community prior to having been acquired by the current owner. However, among farms acquired prior to 2000, this same figure was only 23 percent, whereas since 2000 it has shot up to 69.6 percent, indicating increasing competition over, and dispossession of, land associated with the rise of medium-scale farms. In a dynamic sense, the distributional effects are unclear. It is possible that medium-scale farms, by producing surplus agricultural production and farm labor employment, may kick-start local growth multipliers in a rural economy that otherwise is somewhat stagnant. The medium-scale farms in the sampled areas of Malawi are found to have relatively high labor-to-land ratios compared to other countries in the sub-continent such as Zambia or Ghana [7], where use of labor-saving technologies, such as tractors for plowing and herbicides, has risen significantly in recent years.

Sixth, in terms of the net value of agricultural output per hectare, we find little evidence to suggest that medium-scale farms are more efficient than smaller farms. While our findings do not constitute a formal test of the inverse farm-size/efficiency relationship, we can conclude that there are no clear advantages in land productivity to medium-scale farms over small-scale holdings. Moreover, in the survey data, the ratio of area cultivated to total landholding size is found to decline progressively as farm size increases. Again, the distributional effects of transferring land from a system in which many owner-operators control the means and proceeds of their own production to a system in which that same land is controlled by a few, and the remaining people are converted to low-return farm laborers, may be a topic for the Government of Malawi to examine in much greater detail. In general, the findings of this study, while confined to three districts in Malawi, raise questions about the compatibility between the rapid pace of land transfers to medium-scale farms and the Government of Malawi's national policy goals related to poverty reduction, employment, food security, and agricultural productivity growth.

Lastly, and more broadly, as highlighted in the conceptual framework of this paper, these findings contribute to the development literature on agricultural and structural transformation. The high level of risks and limited economic opportunities may constrain households' options and hence 
their economic returns. This situation can generate possible poverty traps for the smaller-scale and low-income farmers. Malawi's current farm structure thus might not be able to generate broad-based income growth, and hence Malawi cannot rely on agriculture to generate the multipliers that lead to structural transformation [7]. It seems that there is at least circumstantial evidence to suggest that this hypothesis stemming from the structural transformation literature might indeed be true, seeing as how poverty rates have remained relatively high over the past several decades. Considering these socio-economic challenges in light of the land pressure in Malawi, policy orientations should reintegrate these structural issues, stressing the importance of broad-based, inclusive agricultural growth.

Warnings about the effects of non-broad-based agricultural growth and more particularly of rising land conversions from customary land to privately held land in Malawi are not new. Before his assassination in 2003, the Economic Advisor to the President of Malawi, Kalonga Stambuli [32] (p. 15), wrote that: "I have seriously deplored the social injustice and economic marginalization associated with land conversion from communal tenure to leasehold tenure mostly enjoyed by the elite who also enjoyed a monopoly in the production of export crops. Most deplorable is the fact that the abundance of idle land among estates explains much of the low equilibrium trap to which our countries have been subjected. The economic hegemony of the agricultural elite was compounded by state enterprise expansion into the private sector, over-regulation, a stifling bureaucracy, and totalitarian politics. Inadequate amounts of land available to farmers remain a major constraint to supply response."

\section{Conclusions}

This study shows a rapid rise of medium-scale farms in Malawi. Medium-scale farms are defined in this study as agricultural holdings between 5 and 50 hectares. The amount of land acquired by medium-scale holdings in the Mchinji, Kasungu and Lilongwe districts-the three districts examined in this study-is found to have almost doubled between 2000 and 2015. Only 54 percent of the medium-scale holdings resulted from small-scale farmers accumulating land and growing into medium-scale holdings; 46 percent of medium-scale farmers are (or were) pluri-active, non-full-time, and often urban-based. Our findings certainly question the premise that the rise of medium-scale farms in Malawi reflects dynamic agricultural growth and land accumulation among small-scale farmers. Even as medium-scale farmland is increasing rapidly, the majority of rural people in Malawi face acute land scarcity, and household poverty is highly correlated with very small farm size. Lastly, a significant portion of the land acquired by medium-scale farmers was under customary tenure and utilized by others prior to its acquisition, with current owners often successfully transferring the ownership structure of the newly acquired land to a long-term leasehold with a title deed. Farm consolidation, through land acquisitions often by urban-based people, is thus significantly altering the country's land structure and leading to a greater concentration of land assets. These results endorse similar findings in other countries in Africa [6,7].

These conclusions lead to two complementary, broader policy reflections and implications, both of which offer possible avenues for future research. Firstly, the results show that urban-based, local investors and their non-farm income sources may be contributing in important ways to agricultural sector investment and growth. They may also be altering the nature of rural-urban growth linkages [24]. Secondly, the growing focus on how best to exploit Africa's farmland has arguably diverted attention from the more central and enduring challenge of implementing agricultural development strategies that effectively address the continent's massive rural poverty and hunger problems, which require recognition of the growing land constraints faced by much of Africa's rural population. The prospects for inclusive agricultural growth [37]—and with it the ability to make serious progress in eradicating hunger and poverty-may likely depend on open discussions about how to ensure that sufficient land is made available for Africa's rural communities to enable them to contribute to Africa's economic growth processes, rather than be marginalized by more powerful actors-domestic or international—seeking land. 
Acknowledgments: The authors gratefully acknowledge support for this study from the Guiding Investment in Sustainable Agricultural Intensification in Africa (GISAMA) program funded by the Bill and Melinda Gates Foundation, as well as from the Food Security Policy Innovation Lab, which is funded by United States Agency for International Development's Bureau for Food Security.

Author Contributions: The authors confirm that this paper is based on original work engaged in by the authors based on their medium-scale farm survey in the Mchinji, Kasungu and Lilongwe Districts, undertaken by the Lilongwe University of Agriculture and Natural Resources, the University of Pretoria, and Michigan State University (2014-2015).

Conflicts of Interest: The authors declare no conflict of interest.

\section{Appendix A}

Table A1. Landholdings and area cultivated, by farm size in Kasungu district. Source: [27].

\begin{tabular}{|c|c|c|c|c|c|}
\hline & \multicolumn{5}{|c|}{ Farm Size } \\
\hline \# of farms & 65,466 & 16,296 & 2360 & 333 & 84,455 \\
\hline$\%$ of total \# of farms & $77.52 \%$ & $19.29 \%$ & $2.79 \%$ & $0.39 \%$ & $100 \%$ \\
\hline Area cultivated (ha) & $54,972.42$ & $53,659.74$ & $15,104.71$ & $3,615.17$ & $127,352.1$ \\
\hline Total landholdings (ha) & $65,384.01$ & $55,003.41$ & $15,789.75$ & $3,674.50$ & $139,851.7$ \\
\hline$\%$ of Kasungu landholdings that are cultivated & $84.08 \%$ & $97.56 \%$ & $95.66 \%$ & $98.39 \%$ & $91.06 \%$ \\
\hline$\%$ of total landholdings in Kasungu & $46.75 \%$ & $39.33 \%$ & $11.29 \%$ & $2.63 \%$ & $100 \%$ \\
\hline$\%$ of total cultivated land in Kasungu & $43.17 \%$ & $42.13 \%$ & $11.86 \%$ & $2.84 \%$ & $100 \%$ \\
\hline
\end{tabular}

Table A2. Landholdings and area cultivated, by farm size in Lilongwe district. Source: [27].

\begin{tabular}{cccccc}
\hline & \multicolumn{5}{c}{ Farm Size } \\
\cline { 2 - 5 } & $\mathbf{0 - 2}$ ha & $\mathbf{2 . 0 0 1 - 5}$ ha & $\mathbf{5 . 0 0 1 - 1 0 ~ h a ~}$ & $>\mathbf{1 0}$ ha & Total \\
\hline \# of farms & 239,992 & 21,242 & 1940 & 2938 & 266,111 \\
\% of total \# of farms & $90.18 \%$ & $7.98 \%$ & $0.73 \%$ & $1.10 \%$ & $100 \%$ \\
Area cultivated (ha) & $130,288.2$ & $47,649.83$ & $15,852.23$ & $20,072.63$ & $213,862.8$ \\
Total landholdings (ha) & $155,109.6$ & $57,253.25$ & $15,852.23$ & $75,672.09$ & $303,887.2$ \\
Mean farm size (ha) & 0.65 & 2.70 & 8.17 & 25.76 & 1.14 \\
Mean ratio of land cultivated to land owned & 0.83 & 0.85 & $1 *$ & 0.51 & 0.83 \\
\% of Lilongwe landholdings that are cultivated & $84.00 \%$ & $83.23 \%$ & $100 \%$ & $26.53 \%$ & $70.38 \%$ \\
\% of total landholdings in Lilongwe & $51.04 \%$ & $18.84 \%$ & $5.22 \%$ & $24.90 \%$ & $100 \%$ \\
\% of total cultivated land in Lilongwe & $60.92 \%$ & $22.28 \%$ & $7.41 \%$ & $9.39 \%$ & $100 \%$ \\
\hline
\end{tabular}

* Only one household in the sample owns 5-10 ha. Note: excludes Lilongwe city.

Table A3. Landholdings and area cultivated, by farm size in Mchinji district. Source: [27].

\begin{tabular}{|c|c|c|c|c|c|}
\hline & \multicolumn{5}{|c|}{ Farm Size } \\
\hline \# of farms & 81,676 & 8653 & 3668 & 0 & 93,998 \\
\hline$\%$ of total \# of farms & $86.89 \%$ & $9.21 \%$ & $3.90 \%$ & - & $100 \%$ \\
\hline Area cultivated (ha) & $67,059.49$ & $23,476.38$ & $22,451.38$ & - & $112,987.3$ \\
\hline Total landholdings (ha) & $77,190.08$ & 24,666 & $22,619.95$ & - & $124,476.4$ \\
\hline$\%$ of Mchinji landholdings that are cultivated & $86.88 \%$ & $95.18 \%$ & $99.25 \%$ & - & $90.77 \%$ \\
\hline$\%$ of total landholdings in Mchinji & $62.01 \%$ & $19.82 \%$ & $18.17 \%$ & - & $100 \%$ \\
\hline$\%$ of total cultivated land in Mchinji & $59.35 \%$ & $20.78 \%$ & $19.87 \%$ & - & $100 \%$ \\
\hline
\end{tabular}

\section{References}

1. Deininger, K.; Byerlee, D. The Rise of Large-Scale Farms in Land-Abundant Developing Countries: Does It Have a Future? The World Bank: Washington, DC, USA, 2012. 
2. Anseeuw, W.; Boche, M.; Breu, T.; Giger, M.; Lay, J.; Messerli, P.; Nolte, K. Transnational Land Deals for Agriculture in the Global South; Analytical Report Based on the Land Matrix Database; CDE: Bern, Switzerland; CIRAD: Montpellier, France; GIGA: Hamburg, Germany, 2012.

3. Anseeuw, W.; Ducastel, A. "Production grabbing"-New investors and investment models in agriculture. QA Riv. Assoc. Rossi-Doria 2013, 2, 37-55.

4. Reardon, T.; Timmer, C.P.; Barrett, C.B.; Berdegué, J. The rise of supermarkets in Africa, Asia, and Latin America. Am. J. Agric. Econ. 2003, 85, 1140-1146. [CrossRef]

5. Swinnen, J.F. Global Supply Chains, Standards and the Poor; CABI Publishing: Oxfordshire, UK, 2007.

6. Sitko, N.J.; Jayne, T.S. Structural transformation or elite land capture? The growth of "emergent" farmers in Zambia. Food Policy 2014, 48, 194-202.

7. Jayne, T.S.; Chapoto, A.; Sitko, N.; Nkonde, C.; Muyanga, M.; Chamberlin, J. Is the scramble for land in Africa foreclosing a smallholder agricultural expansion strategy? J. Int. Aff. 2014, 67, 35-53.

8. DAFF (Department of Agriculture, Forestry and Fisheries). CASP-Comprehensive Agricultural Support Program; Policy Document. DAFF: Pretoria, South Africa, 2014.

9. Collier, P. The Bottom Billion: Why the Poorest Countries Are Failing and What Can Be Done About It; Oxford University Press: New York, NY, USA, 2008.

10. Sourisseau, J.M.; Bosc, P.M.; Fréguin-Gresh, S.; Belières, J.F.; Bonnal, P.; le Coq, J.F.; Anseeuw, W.; Dury, S. Diversity in Family Farming-Theoretical and Empirical Approaches to its Many Forms; Rethinking Development Working Paper Series, No. 2014/2; University of Pretoria: Pretoria, South Africa, 2014.

11. Lipton, M. Why Poor People Stay Poor; Harvard University Press: Cambridge, MA, USA, 1977.

12. Mellor, J.W. The New Economics of Growth: A Strategy for India and the Developing World; Cornell University Press: Ithaca, NY, USA, 1976.

13. Boussard, J.M. Economie de L'agriculture; Economica: Paris, France, 1987.

14. Timmer, C.P. Handbook of Development Economics; Elsevier: London, UK, 1988.

15. Davies, S. Adaptable Livelihoods; Macmillan Press Ltd.: London, UK, 1996.

16. Ellis, F. Household strategies and rural livelihood diversification. J. Dev. Stud. 1998, 35, 1-38. [CrossRef]

17. Evans, H.E.; Ngau, P.M. Rural-urban relations, household income diversification and agricultural productivity. Dev. Chang. 1991, 22, 519-545. [CrossRef]

18. Reardon, T.; Delgado, C.; Matlon, P. Determinants and effects of income diversification among farm households in Burkina Faso. J. Dev. Stud. 1992, 30, 264-296. [CrossRef]

19. Reardon, T.; Berdegué, J.; Barrett, C.B.; Stamoulis, K. Household income diversification into rural nonfarm activities. In Transforming the Rural Nonfarm Economy; Haggblade, S., Hazell, P., Reardon, R., Eds.; Johns Hopkins University Press: Baltimore, MD, USA, 2006; pp. 115-141.

20. Anseeuw, W.; Laurent, C. Occupational paths towards commercial agriculture: The key roles of farm pluriactivity and the commons. J. Arid Environ. 2007, 70, 659-671. [CrossRef]

21. Fairbairn, M. Indirect expropriation: The role of national institutions and domestic elites in the Mozambican farmland grab. In Proceedings of the International Conference on Global Land Grabbing, Sussex, UK, 6-8 April 2011.

22. Collier, P.; Dercon, S. African agriculture in 50 years: Smallholders in a rapidly changing world? In Proceedings of the Expert Meeting on How to Feed the World in 2050, Rome, Italy, 12-13 October 2009.

23. Timmer, C.P. A World without Agriculture: The Structural Transformation in Historical Perspective; The American Enterprise Institute Press: Washington, DC, USA, 2009.

24. Losch, B.; Fréguin-Gresh, S.; White, E.T. Structural Transformation and Rural Change Revisited: Challenges for Late Developing Countries in a Globalizing World; World Bank Publications: Washington, DC, USA, 2012.

25. Eastwood, R.; Lipton, M. Demographic transition in sub-Saharan Africa: How big will the economic dividend be? Popul. Stud. 2011, 65, 9-35. [CrossRef] [PubMed]

26. Ellis, F. Rural Livelihoods and Diversity in Developing Countries; Oxford University Press: Oxford, UK, 2000.

27. FAO (Food and Agricultural Organization). Country Pasture/Forage Resource Profiles-Malawi; FAO: Rome, Italy, 2015.

28. Republic of Malawi. 2008 Population and Housing Census; National Statistical Office: Lilongwe, Malawi, 2008.

29. Cammack, D.; Kelsall, T.; Booth, D. Developmental Patrimonialism? The Case of Malawi; Working Paper No. 12; Africa Power and Politics Program; Overseas Development Institute: London, UK, 2010. 
30. Stambuli, K. Elitist land and agricultural policies and the food problem in Malawi. J. Malawi Soc.-Hist. Sci. 2002, 55, 34-83.

31. Mhone, G.C.Z. Malawi at the Crossroads: The Post-Colonial Political Economy; SAPES Books: Harare, Zimbabwe, 1992.

32. Mtewa, M. Malawi Democratic Theory and Public Policy; Schenkman Books: Cambridge, MA, USA, 1986.

33. Chikaipa, V. A critique of the government responses on oppositions and protests over land grabs in Malawi: A case study of the Chinese and Madonna's Raising Malawi project land leases in Salima and Lilongwe districts respectively. In Proceedings of the International Conference on Global Land Grabbing II, Cornell University, Ithaca, NY, USA, 17-19 October 2012.

34. World Bank. 2013 Integrated Household Panel Survey in Malawi; The World Bank: Washington, DC, USA, 2013.

35. Lowder, S.; Skoet, J.; Raney, T. Making better use of agricultural census data to understand farmland distribution. In Proceedings of the World Bank Conference on Land and Poverty, Washington, DC, USA, 23-27 March 2015.

36. Ricker-Gilbert, J.; Jumbe, C.; Chamberlin, J. The impact of increasing population density on African agriculture and livelihoods: The case of Malawi. Food Policy 2014, 48, 114-128. [CrossRef]

37. OECD. African Economic Outlook—Regional Development and Spatial Inclusion; OECD: Paris, France, 2015.

(c) 2016 by the authors; licensee MDPI, Basel, Switzerland. This article is an open access article distributed under the terms and conditions of the Creative Commons Attribution (CC-BY) license (http:/ / creativecommons.org/licenses/by/4.0/). 